Discussion Paper No. 15-048

Facility- and Service-based Competition and Investment in Fixed Broadband Networks: Lessons from a Decade of

Access Regulations in the European Union Member States

Wolfgang Briglauer, Klaus Gugler, and Adhurim Haxhimusa

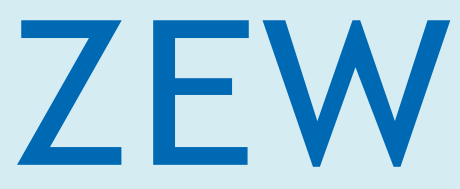

Zentrum für Europäische Wirtschaftsforschung $\mathrm{GmbH}$ Centre for European Economic Research 
Discussion Paper No. 15-048

\title{
Facility- and Service-based Competition and Investment in Fixed Broadband Networks: Lessons from a Decade of Access Regulations in the European Union Member States
}

\author{
Wolfgang Briglauer, Klaus Gugler, \\ and Adhurim Haxhimusa
}

Download this ZEW Discussion Paper from our ftp server:

http://ftp.zew.de/pub/zew-docs/dp/dp15048.pdf

Die Discussion Papers dienen einer möglichst schnellen Verbreitung von neueren Forschungsarbeiten des ZEW. Die Beiträge liegen in alleiniger Verantwortung der Autoren und stellen nicht notwendigerweise die Meinung des ZEW dar. 
Facility- and Service-based Competition and Investment in Fixed Broadband Networks: Lessons from a Decade of Access Regulations in the European Union Member States

\section{Wolfgang Briglauer*, Klaus Gugler**, Adhurim Haxhimusa**}

May 2015

*) (Corresponding author) Centre for European Economic Research (ZEW Mannheim), e-mail: briglauer@zew.de, phone: +49 (0) 621 1235-279, P.O. Box 103443, 68034 Mannheim, Germany.

${ }^{* *}$ ) Vienna University of Economics and Business (WU), Research Institute for Regulatory Economics, Vienna, Austria, e-mail: klaus.gugler@wu.ac.at, adhurim.haxhimusa@wu.ac.at.

\section{Keywords}

Investment dynamics, regulation, service-based competition, facility-based competition, strategic effects

JEL

L43, L52, L96 


\begin{abstract}
This paper employs firm-level panel data of 57 incumbent and entrant firms for 23 European countries in the decade from 2003 to 2012. We examine the impact of service- and facility-based competition on firm-level investment as well as the strategic effects underlying infrastructure investment decisions. At the same time we explicitly model the structural dynamics of broadband investment by means of a flexible accelerator model. The empirical specification employs dynamic panel estimation techniques which allows us to account for various sources of endogeneity. We find that facility-based competition exerts a positive and significant impact on both incumbents and entrants implying that incumbents' and entrants' investment decisions are strategic complements. Moreover, we find that intermodal competition in terms of fixed-mobile substitution exerts different effects at the firm level. Finally, we show that service-based competition appears to have no significant impact on the investment decision of incumbents and entrants. However, with respect to the later phase of market liberalization, service-based competition exerts a negative impact on entrants' investment. Our results thus also provide relevant policy guidance on the role of service-based competition in regulating emerging high-speed broadband infrastructure.
\end{abstract}




\section{Introduction}

Following the liberalization of electronic communications markets in 1997/1998, the European Commission (EC) issued several guidelines to introduce competition in those markets by means of mandated wholesale access obligations. Typically, these obligations were asymmetrically imposed on formerly state-owned "incumbent" operators who were deemed to have significant market power related to the possession of monopoly-like legacy infrastructure. In particular, the EC in its Directive 2887/2000 has foreseen mandated wholesale access to the local loop (European Parliament \& Council, 2000) and thus enabled new market operators ("entrants") to offer retail narrowband voice and broadband services directly to customers. Service-based competition that hinges directly upon a set of pre-defined access regulations and costoriented wholesale access charges, in particular, allows the entrant to offer competitive retail services without getting engaged in timely, costly, and risky roll-out of own access network infrastructure, if access obligations are effectively implemented by the national regulatory authorities (NRAs). In the early stages of market liberalization service-based competition massively increased price competition and thus had an immediate and positive welfare effect in terms of static efficiency.

The EC also emphasized in its Directive 2002/19/EC that mandated access should not reduce the incentives of entrants to invest in alternative infrastructure (European Parliament \& Council, 2002). The latter, in turn, would be essential to foster competition in the long-run in terms of dynamic efficiency. Moreover, infrastructure- (or: facility-) based competition involves a much lower degree of industry micromanagement and hence lower administrative costs. However, the EC has never explicitly mandated the entrant to start investing in its own access network after a certain period of time, with a formal requirement to enter facility-based competition. Consequently, the decision to invest in own facilities is up to the entrant contingent, inter alia, on regulatory investment conditions. As a result, wireline communications markets are still characterized by two different types of entrants, those who remain servicebased competitors, and those who gradually self-deploy network infrastructure and thus also enter facility-based competition becoming at least partly independent network 
operators. The latter development adheres to the so-called "ladder of investment" (Lol) hypothesis (Cave \& Vogelsang, 2003; Cave, 2006). According to this hypothesis, regulatory-induced service-based competition serves as a stepping stone for entrants to engage progressively in backward integration and ultimately to self-deploy access infrastructure. ${ }^{1}$ The former, however, still represents by far the predominant group of entrants. $^{2}$

One of the most controversial questions is which mode of competition is preferable in order to lower prices and to achieve high investment at the same time. This issue becomes even more important in view of the deployment of fiber-based next (or second) generation communications infrastructure; in particular, it is hotly debated whether emerging communications infrastructure should be subjected to a similar set of sector-specific access regulations and whether service-based competition is essential, in a similar way as in the beginning of liberalization of first-generation broadband networks, or if it rather diminishes ex ante investment incentives. ${ }^{3}$ Infrastructure-based operators argue that service-based competition via mandatory access regulations restricts their ability to generate sufficient revenues and would thus be detrimental to ex ante investment incentives and network innovations. Conversely, for NRAs and servicebased entrants a potential threat of new and possibly more intense monopoly areas arises in the course of the deployment of new fiber-based infrastructure, which entails the need to have again an appropriate access regulation in place.

Utilizing the experience of a decade of regulating first-generation broadband networks, our paper intends to draw lessons from the impact of both modes of competition on investment in fixed broadband markets. In addition, we examine the impact of wireless ("intermodal") competition from mobile networks on investment

\footnotetext{
${ }^{1}$ Hence in the U.S. the Lol hypothesis is known as the "stepping stone" hypothesis.

2 In principle, there might be a continuum between pure service-based competition and facility-based competition (Guthrie, 2006). However, in broadband/telecommunications markets one has basically observed the following categories of operators during the entire period of market liberalization: i) incumbent firms that were subject to sector-specific and asymmetric ex ante regulations imposed on legacy infrastructure, and, ii) entrant firms either with own access infrastructure, such as cable TV networks ("infrastructure or facility-based operators") or without ("service-based operators" relying on wholesale access obligations).

${ }^{3}$ The reader is referred to Telecommunications Policy special issue published in 2013 (Volume 37(10)) which collects controversial papers on the topic "Regulatory approaches and investment in new communications infrastructure".
} 
activities of fixed broadband operators. In answering this, we employ an unbalanced panel data set of 57 operators from 23 European Union (EU) member states for the years from 2003 to 2012. The period of analysis thus covers the beginning of servicebased competition in broadband markets up to the early phase of transition to next generation infrastructure deployment that has been initiated only a few years ago in most EU member states. We therefore exploit information over a whole decade of market liberalization and regulation involving all relevant sources of competition in order to have a sound basis to derive reliable recommendations for future (de-)regulatory policies to be imposed on new communications infrastructure.

Our empirical specification incorporates: i) generalized methods of moments (GMM) and bias-corrected fixed effects estimators to account for the endogeneity bias due to the dynamic specification of the investment equation, omitted variables and reverse causality patterns; ii) strategic firm-level effects regarding investment decisions, and finally, iii) the structural dynamics of adjustment costs in terms of a dynamic investment accelerator model.

The remainder of the paper is organized as follows: Section 2 reviews the related and recent empirical literature. Section 3 outlines our basic hypotheses. Section 4 describes the data set underlying our empirical investigation. Section 5 presents the empirical baseline specification and our identification strategy. Section 6 describes and interprets the main results of the empirical analysis. Section 7 summarizes and compiles important assessments for future regulatory policies.

\section{Empirical evidence}

In this section we review the most related and recent contributions from the empirical literature. In doing this, we build on the well-cited survey by Cambini and Jiang (2009) who review the older literature on investment and regulation. The authors conclude that the majority of the contributions find that service-based competition in terms of different forms of cost-based access regulations discouraged both incumbents and entrants from investing in fixed networks. In the following we also consider empirical studies that 
employ measures of broadband penetration which is output-related and hence might provide a better proxy for consumer welfare.

Bouckaert et al. (2010) examine the determinants of broadband penetration based on data for 20 OECD countries for the years from 2003 to 2008 . The authors find that infrastructure-based competition has a positive impact on broadband penetration, whereas service-based competition is an impediment to penetration. The authors argue that their findings suggest that the Lol hypothesis does not provide sufficient justification for imposing comprehensive broadband access regulations. Grajek and Röller (2011) empirically estimate the relationship between regulation and investment as regards telecommunications investment of incumbent and entrant operators using data for EU member states for the years from 1997 to 2006. Using a formal regulatory index the authors find that access regulation reduces both individual firm and total industry investment. Moreover, the authors find that incumbents invest more in response to investment increases of entrants indicating that investments are strategic complements, although the complementarity is not significant the other way around, i.e. from the incumbents to entrants. Bacache et al. (2014) examine the incentives embedded in the EU regulatory framework on migration from old to new fiber-based access infrastructures using data from $15 \mathrm{EU}$ member states for 17 semesters over the period from July 2002 to July 2010. The authors relate the number of access lines based on new access technologies to the number of unbundling and bitstream lines. Whereas the authors find some support for the Lol hypothesis for the migration from bitstream access to local loop unbundling at the lower rungs of the ladder with lower investment requirements, there is no empirical support for the hypothesis that mandatory local loop unbundling fosters entrants to invest in new and much more cost intensive access infrastructures. Nardotto et al. (2015) find similar results using broadband penetration data from December 2005 to December 2009 for the whole of the UK. The authors find support for a short ladder leading from resale to bitstream access and unbundling but not to self-deployed entrants' access infrastructure. Crandall et al. (2013) is a recent OECD based study that utilizes country level data for the years from 2001 to 2010 . The authors find that unbundling obligations have almost no significant impact on broadband penetration in the short run but a significantly negative impact on penetration in the long 
run. Finally, Briglauer et al. (2013) are the first to investigate the determinants of fiberbased infrastructure deployment using data for the years from 2005 to 2011 . Their empirical specification incorporates real investment data for the EU27 states. The authors find that the more effective wholesale broadband access regulation and hence service-based competition is, the more negative is the impact on fiber deployment. Intermodal competition from mobile networks exerts a non-linear impact on aggregate investment in terms of an inverted U-shape relationship.

Summarizing, the recent empirical analysis on wholesale access regulations and investment seems to prove the results in Cambini and Jiang (2009), according to which service-based competition and related broadband access regulations tend to be either statistically unrelated or negatively related to investment incentives. Furthermore, there is evidence that infrastructure-based competition exerts a positive impact on investment at the aggregate level. To the best of the authors' knowledge, there is no empirical work that employs firm-level investment data, incorporates the structural dynamics of broadband investment and simultaneously takes into account both modes of competition as well as the relevant sources of endogeneity. This paper intends to fill this gap and identify the causal effects of service-based and facility-based competition on broadband investment during the relevant period of broadband market liberalization and regulation.

\section{Hypotheses}

This section identifies the main determinants of broadband investments in Europe in the decade from 2003 to 2012 and sets out corresponding hypotheses, which are aligned to the main modes of competition in broadband markets: Service-based competition (Section 3.1) and facility-based competition (Section 3.3). Moreover, we explicitly outline the dynamics of broadband investment in terms of a flexible accelerator investment model (Section 3.4). 


\subsection{Service-based competition}

At the beginning of market liberalization, EU member states introduced asymmetric (one-way) access regulations imposed on the incumbent operators, which enabled service-based competition at cost-oriented access charges directly set by NRAs. The EU regulatory framework basically provides three different kinds of wholesale access obligations, namely: i) "resale", ii) "bitstream", and iii) "unbundling". Simple resale means that the entrant sells the services of the incumbent with no technical scope of product differentiation. In this case the entrant is hardly confronted with fixed and sunk costs. In the case of bitstream, the entrant has to build its own backbone network, which enables him to differentiate the quality characteristics of its retail services to some extent. In the case of unbundling, the entrant operates much more independently, since it gets physical access to the incumbent's local loop copper lines.

In view of these multi-level wholesale access remedies, the Lol hypothesis has been considered as a guiding principle in the EU regulatory framework tool to promote both price competition and broadband investment (ERG, 2005) and hence to resolve the classical trade-off between dynamic and static efficiency. An entrant that gradually invests moving from rung to rung (from simple resale to bitstream and then to unbundling and finally to self-deployed infrastructure) adds value to its services and operates more and more independently; service-based entrants will first acquire more information and establish a customer base, and therefore they will be ultimately able to invest in their own infrastructure, which then results in facility-based competition representing the top of the ladder (Briglauer \& Gugler, 2013). Ideally, facility-based and service-based competition result in lower retail prices and increased product variety, which may also lead to an increase in total demand for broadband services. This demand increasing effect might also increase investment incentives by incumbents (Foros, 2004; Kotakorpi, 2006). Moreover, in the case of excessive capacities, when more downstream competition decreases retail prices, which in turn may be associated with an increase in total demand, it could be the case that the regulated incumbent is almost one-to-one compensated for foregone monopoly profits. From this point of view, rather than being substitute competition modes, service- and facility-based competition 
would complement each other and there would be no inter-temporal trade-off between static and dynamic efficiency.

However, several other effects predict that more intense service-based competition deteriorates investment incentives of incumbent and/or entrant operators: first, the incumbent will only be able to make monopoly profits until asymmetric access regulation is introduced which enables market entrance at cost-oriented access charges. This is because rents earned from wholesale access at cost-oriented prices are lower than monopoly rents from selling infrastructure directly to retail customers. This effect gets reinforced in case risks are shifted from entrants to incumbents, which is typically the case under standard cost-based access regimes (Pindyck 2007; Valletti 2003). Guthrie (2006) and Bourreau and Dogan (2006) emphasize that the ex ante regulated incumbent is exposed to a considerable risk, while the entrant has investment flexibility in terms of exploiting new technologies. Innovations, such as xDSL technologies, enable the entrant to offer new products or higher quality services without facing the risk due to demand uncertainties. Thus, open access policies enable servicebased entrants to avoid investment in unsuccessful technologies after getting sufficient information from the market. Guthrie (2006) criticizes that regulatory access obligations typically do not incorporate the option value of "wait and see strategies" that servicebased entrants obtain. Overall, favourable access regulations constitute substantial opportunity costs for entrants' investment and may thus postpone or hinder their infrastructure investment.

Summarizing, service-based competition exerts a positive impact on entrants' investment incentives only if multilayer access induces further investment activities and dominates entrants' opportunity costs (representing the benefit from cheap access). With respect to the investment incentives of the incumbent the net effect is indeterminate to the extent that service-based competition simultaneously captures negative investment incentives related to (standard cost-based) access regulations, as well as the demand expanding effect according to which total revenues increase with the level of service-based competition. 


\subsection{Facility-based competition}

In this section we add another dimension of competition stemming from alternative wireline broadband operators, namely the entrant's own self-deployed access lines, which represent facility-based competition that does not depend on any kind of asymmetric wholesale access regulations. The entrant by investing in facility-based access infrastructure enjoys additional benefits referring to entrepreneurial independency or better quality of service and it avoids paying the access charge to the incumbent. In reality, however, besides incumbents only operators with access to infrastructure elements prior to market liberalization substantially invested in deploying access networks. Most notably, these networks refer to coax-cable broadband infrastructure with prior cable TV networks or municipal utilities with prior duct infrastructure. In turn, service-based competition did not induce any substantial selfdeployed access infrastructure on the side of pure service-based entrants as evidenced in the empirical literature (Bacache et al. (2014); Boukaert et al. (2010); Nardotto et al. (2015)). According to Vogelsang (2013, p. 212) this can be interpreted as the "natural outcome of the economics of fixed broadband access". Bender and Goetz (2011) provide a theoretical explanation why entrants ultimately refrain from self-deploying access infrastructure. The authors model competition between the incumbent and an entrant who faces a make-or-buy decision as regards the upstream level. The authors argue that service-based entrants have, in principle, an incentive to invest in view of possible cost savings but are also confronted with a strategic effect: lower costs enable lower retail prices, however, these might imply aggressive pricing and investment reactions from the incumbent in order to limit consumer migration to the entrants' retail services.

Wireline facility-based competition stemming from entrant operators hereinafter refers to access networks of cable operators complemented by some municipal investment activities which is distinctively different from activities of service-based entrants relying on access regulations. Regarding the relationship between facilitybased competition and investment, there is no clear prediction at the micro-level as shown in Sacco and Schmutzler (2011) in general. Rather, the relationship depends on the definition of competitive intensity and the oligopoly framework and consequently 
investments can be increasing or decreasing functions of competition. However, it is well-known from the pre-emption literature that a potential infrastructure provider has an incentive to pre-empt another infrastructure provider by being the first and thus reducing the rivals' profitability and incentives to invest. As a consequence, infrastructure providers might get engaged in a race to invest first and earn the rents if there is a firstmover advantage. Such a pre-emption race is of particular relevance for investment upgrades in telecommunications (Gans, 2001; Guthrie, 2006; Vareda \& Hoernig, 2010; Grajek \& Röller, 2011) where infrastructure duplication is only possible in areas with high population density whereas in all other areas - due to the economics of fixed broadband access - infrastructure investment is only profitable, if at all, for one operator. This opens up the potential for a long-lasting first-mover advantage which thus fosters ex ante investment incentives. In addition, as shown in Bourreau et al. (2012, p. 719), in case entrant operators benefit from sufficiently large investment spillovers, investment decisions become strategic complements. The authors argue that entrants total investment costs may be lower in areas where the incumbent operator has already incurred substantial administrative and contractual costs. Finally, Hori and Mizuno (2006) show that an incentive for pre-emption exists in an open access regulatory framework with uncertain demand. Again, both features appear to be characteristic for deployment of broadband infrastructure.

Summarizing, incumbents' and entrants' infrastructure investment decisions mutually reinforce each other, i.e. investment decisions are strategic complements, if i) the operators engage in pre-emption strategies and "race" for the first-mover advantage in terms of aggressive price competition at the retail level and infrastructure investment, ii) investment spillover effects are sufficiently large or iii) if operators are subject to an open access framework with sufficiently high access charges and uncertain demand. As regards the role of facility-based competition from (intermodal) mobile networks there is no clear prediction concerning the functional relationship and the net impact on firmlevel investment. 


\subsection{Investment dynamics: a flexible accelerator model}

Below we present a flexible accelerator investment model using a neoclassical production function with constant returns to scale and no substitution between input factors. Thus, it only takes into account quantity variables, while price variables are not included (Chirinko, 1993). The first derivative and cross partials of the production function are positive and the second derivatives are negative. This implies that the marginal products are positive at decreasing rates and are positively related to other input factors employed. Thus, increasing the output level would require an increase in inputs, following the objective of cost minimization and depending on the adjustment cost (Eisner, 1978).

The main and most important assumption of this model is about the firm's desired level of capital expressed in terms of a fixed capital to output ratio. We denote the desired level of capital of the firm $i$ at time $t$ by $K_{i, t}^{*}$, the output level by $Y_{i, t}$ and the capital to output ratio by $\alpha$. Based on the notion of optimal capital accumulation, the optimal level of capital is proportionally related to the level of output:

$$
K_{i, t-1}^{*}=\alpha Y_{i, t-1}
$$

where $K_{i, t-1}^{*}$ and $Y_{i, t-1}$ represent the desired level of capital and the output level of the firm $i$ in the previous period of time $t-1$, respectively. Consequently, a high capital to output ratio is associated with high investment expenditures, and vice versa. In the simple accelerator investment model $\alpha$ is constant. If the adjustment is immediate and ignoring depreciation, investment would be simply the difference in the desired capital stocks in period $t$ and $t-1$ :

$$
I_{i, t}=\left(K_{i, t}^{*}-K_{i, t-1}^{*}\right)=\alpha\left(Y_{i, t}-Y_{i, t-1}\right) \equiv \alpha \Delta Y_{i, t}
$$

where $I_{i, t}$ represents current investment in period $t$ for firm $i$. However, the older literature (Eisner, 1978) as well as recent and telecommunications related evidence (Briglauer et al., 2013; Grajek \& Röller, 2011) suggest that it is unlikely that firms fully adjust their capital stock due to a change in the output level in the current period of time (in our case, within one year). Accelerator investment models where changes in the 
level of capital require longer time to move toward a new equilibrium implied by a change in the level of output are referred to as flexible accelerator investment models. Furthermore, it is assumed that changes in the capital stock from year $t-1$ to year $t$ follow an adjustment process by a proportion $1-\lambda$ of the difference between the actual and desired level of capital:

$$
K_{i, t}-K_{i, t-1}=(1-\lambda)\left(K_{i, t}^{*}-K_{i, t-1}\right)
$$

Next, we introduce replacement investment, i.e. the rate of the capital depreciation, in the flexible accelerator mechanism. As a result, the capital stock is expressed as the sum of the previous capital stock and the level of current investment minus the depreciation of the previous level of the capital stock (Jorgenson \& Siebert, 1968):

$$
K_{i, t}=K_{i, t-1}+I_{i, t}-\delta K_{i, t-1}
$$

where $\delta$ represents the constant rate of depreciation. From equation (4) we solve for $I_{i, t}$ and obtain:

$$
I_{i, t}=K_{i, t}-(1-\delta) K_{i, t-1}
$$

From the flexible accelerator mechanism in equation (3) we now solve for $K_{i, t}$ and obtain:

$$
K_{i, t}=(1-\lambda) K_{i, t}^{*}+\lambda K_{i, t-1}
$$

To complete the flexible accelerator investment model we insert equation (6) into equation (5) and obtain:

$$
I_{i, t}=(1-\lambda) K_{i, t}^{*}-(1-\delta) K_{i, t-1}+\lambda K_{i, t-1}
$$


Finally, we integrate the capital to output ratio and the investment dynamics as captured by the lagged dependent variable to obtain the dynamic flexible accelerator investment model: ${ }^{4}$

$$
I_{i, t}=\lambda I_{i, t-1}+\alpha(1-\lambda) Y_{i, t}-\alpha(1-\delta)(1-\lambda) Y_{i, t-1}
$$

Summarizing, if broadband investment is subject to a partial adjustment process, we expect that the coefficient estimate of the lagged dependent variable, $\lambda$, lies in the interval $[0 ; 1]$ where the lower limit indicates that adjustment takes place instantaneously and the upper limit indicates complete persistence, i.e. there is no convergence towards an optimal desired long-run broadband infrastructure stock. Furthermore, with $\alpha>0$ and $0<\delta<1$ we expect that the coefficient estimate of the (lagged) output variable is positive (negative).

\section{Data and variables}

Our data set covers $23 \mathrm{EU}$ member states and 57 firms, including 21 incumbents and 36 entrants for the years from 2003 to 2012. Our panel data set is unbalanced, since data availability regarding the start and end of the time period varies by firms and countries. We use the following main data sources: EU progress reports provide country level data on total broadband lines, i.e. regulated wholesale lines, entrants' own lines and incumbents' own lines; Worldscope provides firm-level data regarding capital expenditures (CAPEX), tangible fixed assets, sales and cash flow. Our sample comprises 57 different firms ${ }^{5}$ which vary widely in their size.$^{6}$ Hence, we divide CAPEX, sales and cash flows by the one period-lagged tangible fixed assets. The lagged tangible fixed assets are used in order to eliminate the possibility of endogeneity

\footnotetext{
${ }^{4}$ The reader is referred to the Appendix for a detailed derivation of the accelerator model.

5 The Orbis database enables the identification of firms that operate in wireline telecommunications markets with NACE code number 611010. For the resulting list of operators we verified which firms are registered on the Stock Exchange Markets based on the International Securities Identification Number (ISIN) which then enabled us to get the firm-level data from the Worldscope database.

6 There is a big difference not only between the incumbents and entrants, but also within incumbents and entrants. For example the mean of CAPEX of the Austrian incumbent, A1 Telecom Austria, is $€ 689$ million, while the mean of CAPEX of the Malta incumbent, GO PLC, is $€ 18$ million. On the other hand, the mean of CAPEX of the entrant German Freenet AG is $€ 80$ million, while the mean of CAPEX of the Polish entrant Telestrada SA is $€ 47$ thousand.
} 
between CAPEX and tangible fixed assets, since increasing CAPEX may increase tangible fixed assets of the current period. In addition, we use several other data sources for our control variables: the World Bank (The World Development Indicators) for data on GDP per capita and the International Telecommunications Union (World Telecommunication/ICT Indicators Database) for data on the number of personal computers in use per capita and fixed-to-mobile substitution. Finally, the European Central Bank and MarketLine provide data on the long term interest rate and population density, respectively.

\subsection{Dependent variable}

Our dependent variable, capex_as, represents firm level CAPEX divided by the lagged tangible fixed assets in the telecommunications industry in terms of property, plant and equipment. This contains, most notably, investment in backbone and access networks. Note that whereas most of the incumbents are active in both fixed and mobile broadband markets, the entrants included in our sample are mainly offering fixed broadband services only.

\subsection{Independent variables}

Based on our hypotheses we divide our explanatory variables into the following three groups: i) service-based competition ii) facility-based competition, and iii) control variables. The latter category contains variables related to our dynamic investment accelerator model as well as demand and cost controls.

First, service-based competition, $s b c$, is measured by dividing the number of regulated lines (including unbundling, bitstream and simple resale lines) by the sum of the regulated lines and incumbent's retail lines, thus showing the share of incumbent's lines made available through the regulated wholesale market. Hence, this variable captures the market effect of regulatory-induced service-based competition. The variable $s b c$ incorporates both the wholesale and retail market, since incumbent's retail lines represent the lines which the incumbent uses internally to deliver its services to the customers in the retail market. 
Facility-based competition, $f b c$, is directly related to wireline infrastructure investment of both the incumbent and entrants and measured in physical units. Therefore, we employ two different variables which enables the estimation of strategic effects regarding the incumbent's and entrants' investment decisions. First, facilitybased competition is obtained as the share of the entrants' own lines related to the total number of retail broadband lines, $f b c_{-} e n t$. Entrants' own lines show the number of broadband lines that are directly connected to entrants' self-deployed infrastructure by using other technologies than DSL (e.g. cable, fibre, WLL but excluding WiFi). Most notably, entrants' own lines represent real investments of cable operators and municipalities. Second, wireline facility-based competition is measured by the variable, $f b c \_i n c$, which is obtained as the share of the incumbent's retail lines related to total number of retail broadband lines. Finally, the variable $f m s$ measures intermodal wireless competition in terms of the extent of fixed-to-mobile competition by relating the total number of mobile lines to a country's total number of fixed landlines.

Regarding the group of control variables, we first refer to the variables related to our dynamic investment accelerator model. With respect to the desired level of capital stock $\left(K^{*}\right)$, there are different theories that assume that the desired level of capital stock is proportional to different indicators of business activity. According to the capacity utilization theory, the level of CAPEX is positively related to the capital to output ratio (Jorgenson \& Siebert 1968). According to Eisner (1978), applying sales as a main observable (proxy) variable of output $(Y)$, the capital stock is expected to change with changes in sales and, thus, CAPEX are taken as a distributed lag function of current and past sales. Accordingly, we include the sales to tangible fixed assets ratio, sales_as, and the one period lagged sales to tangible fixed assets ratio. Moreover, we introduce an additional firm level variable, namely the cash flow to tangible fixed assets ratio, cflow_as. Fazzari et al. (1988) examine the effects of asymmetric information on access to external funds and thus on the firms' investment level. The authors conclude that firms that are financially constrained are more sensitive to the availability of internal funds, such as cash flow. There is a large literature that investigates the relationship between investment and cash flow taking into account different factors that might explain this relationship, including creditworthiness, size and ownership structure (Bond 
et al., 2003; Gugler, 2003; Kaplan \& Zingales, 1997; Vermeulen, 2002). So, different coefficient estimates for the variable $c f l o w_{-} a s$ in the incumbents' and entrants' equations point to different levels of cash constraints.

Finally, we employ additional country-level control variables to capture demand and cost side investment determinants: i) GDP per capita, $g d p_{-} p c$, captures the income effects at the country level; ii) the number of personal computers in use per capita, comp_pc, reflects the importance of the information technologies for the population (assuming that each computer has an internet connection) and also stands proxy for the overall broadband market size; iii) the long-term interest rate, $l t_{-} i r$, is expected to capture the cost of capital for long-term telecommunications investment; iv) population density, pop_dens, shows different cost structures due to varying population densities across countries.

All descriptive statistics as well as variable definitions, expected signs and sources are listed below in Table 1 and Table 2, respectively.

Table 1: Descriptive statistics

\begin{tabular}{|c|c|c|c|c|c|}
\hline Variable & Observations & Mean & Std. deviation & Min & Max \\
\hline & \multicolumn{5}{|c|}{ Firm level (Incumbents) } \\
\hline capex_as & 198 & 0.1820 & 0.0676 & 0.0361 & 0.3244 \\
\hline sales as & 198 & 1.3614 & 0.5036 & 0.4197 & 2.7091 \\
\hline \multirow[t]{2}{*}{ cflow_as } & 198 & 0.3919 & 0.1372 & 0.1165 & 0.7541 \\
\hline & \multicolumn{5}{|c|}{ Firm level (Entrants) } \\
\hline capex_as & 244 & 0.4136 & 1.6948 & 0.0007 & 26.3725 \\
\hline sales as & 302 & 12.2836 & 17.2654 & 0.0730 & 105.4997 \\
\hline \multirow[t]{2}{*}{ cflow_as } & 300 & 0.5877 & 3.4281 & -26.8139 & 10.0706 \\
\hline & \multicolumn{5}{|c|}{ Country level } \\
\hline$s b c$ & 216 & 0.2566 & 0.1751 & 0.0002 & 0.6952 \\
\hline fbc_inc & 218 & 0.4931 & 0.1313 & 0 & 0.9438 \\
\hline fbc_ent & 215 & 0.3102 & 0.1837 & 0.0029 & 0.7613 \\
\hline$f m \bar{s}$ & 230 & 4.6050 & 0.8296 & 0.8721 & 5.9 \\
\hline$g d p \_p c$ & 230 & 21787 & 11385 & 2349 & 43831 \\
\hline comp_pc & 230 & 0.4730 & 0.2744 & 0.0551 & 1.2329 \\
\hline It_ir & 230 & 4.652 & 2.2211 & 0.57 & 22.5 \\
\hline pop_dens & 230 & 182.397 & 254.5591 & 17.1369 & 1280.74 \\
\hline
\end{tabular}


Table 2: Variable descriptions and sources

\begin{tabular}{|c|c|c|}
\hline $\begin{array}{c}\text { Variable } \\
\text { (expected sign) }\end{array}$ & Description & Source \\
\hline & Dependent variable & \\
\hline \multirow[t]{2}{*}{ capex_as } & $\begin{array}{l}\text { Firm capital expenditures divided by lagged tangible } \\
\text { fixed assets (property, plant and equipment) - capital } \\
\text { expenditures to tangible fixed assets ratio. Firm capital } \\
\text { expenditures are measured in Euros. }\end{array}$ & Worldscope \\
\hline & Main explanatory variables & \\
\hline $\begin{array}{l}\text { sbc } \\
\text { (+/- incumbent; } \\
+/- \text { entrant) }\end{array}$ & $\begin{array}{l}\text { Regulated lines (including unbundling, bitstream and } \\
\text { simple resale lines) divided by the sum of regulated } \\
\text { lines and incumbent's retail lines. }\end{array}$ & $\begin{array}{l}\text { EU Digital Agenda } \\
\text { Scoreboard }\end{array}$ \\
\hline$f b c \_$ent $(+)$ & $\begin{array}{l}\text { The share of the entrants' own lines related to total } \\
\text { number of retail broadband lines. }\end{array}$ & $\begin{array}{l}\text { EU Digital Agenda } \\
\text { Scoreboard }\end{array}$ \\
\hline fbc_inc (+) & $\begin{array}{l}\text { The share of the incumbent's retail lines related to total } \\
\text { number of retail broadband lines. }\end{array}$ & $\begin{array}{l}\text { EU Digital Agenda } \\
\text { Scoreboard }\end{array}$ \\
\hline \multirow[t]{2}{*}{$\begin{array}{l}\text { sales_as (+) } \\
\text { Lag: sales_as (-) }\end{array}$} & $\begin{array}{l}\text { Firm sales divided by lagged tangible fixed assets } \\
\text { (property, plant and equipment) - sales to tangible fixed } \\
\text { assets ratio. Firm sales represent gross sales and } \\
\text { other operating revenue less discounts, returns and } \\
\text { allowances }{ }^{7} \text {. Firm sales are measured in Euros. }\end{array}$ & Worldscope \\
\hline & Control variables & \\
\hline cflow_as (+) & $\begin{array}{l}\text { Firm cash flow divided by lagged tangible fixed assets } \\
\text { (property, plant and equipment) - cash flow to tangible } \\
\text { fixed assets ratio. Firm cash flows are measured in } \\
\text { Euros. }\end{array}$ & Worldscope \\
\hline fms (+/-) & Ratio of mobile lines to fixed landlines. & $\begin{array}{c}\text { World } \\
\text { Telecommunication/ } \\
\text { ICT Indicators Database }\end{array}$ \\
\hline$g d p \_p c(+)$ & Gross domestic product per capita in Euro. & $\begin{array}{l}\text { The World Bank - The } \\
\text { World Development } \\
\text { Indicators }\end{array}$ \\
\hline comp_pc (+) & $\begin{array}{l}\text { The number of personal computers in use normalized } \\
\text { to population. }\end{array}$ & $\begin{array}{c}\text { World } \\
\text { Telecommunication/ } \\
\text { ICT Indicators Database }\end{array}$ \\
\hline It_ir (-) & $\begin{array}{l}\text { Harmonized long-term interest rates among the EU } \\
\text { Member States. The rates were accessed as } \\
\text { secondary market yields of government bonds with a } \\
\text { remaining maturity of ten years. }\end{array}$ & $\begin{array}{l}\text { EU Digital Agenda } \\
\text { Scoreboard }\end{array}$ \\
\hline pop_dens (+) & $\begin{array}{l}\text { A country's population density in persons per square } \\
\text { kilometre. }\end{array}$ & MarketLine \\
\hline
\end{tabular}

7 It excludes: non-operating income, interest income, interest capitalized, equity in earnings of unconsolidated subsidiaries, rental income, dividend income, foreign exchange adjustment, gain on debt retired, sale of land or natural resources, sale of plant and equipment, sale of investment, sales from discontinued operations, security transactions, general and service taxes, value-added taxes, etc. 


\section{Econometric modelling}

First, we describe our empirical baseline specification in section 5.1 and then our estimation and identification strategy in section 5.2 .

\subsection{Econometric specification}

Our baseline specification refers to a dynamic reduced-form model in which investment expressed in monetary terms is specified for the operator $i$ in EU member state $j$ and year $t$ as follows:

$$
\begin{aligned}
\text { capex_as } & =\gamma+\beta_{0} \text { capex_t }_{-} a s_{i, t-1}+\beta_{1} \text { sales_as } s_{i, t}+\beta_{2} \text { sales_as } s_{i, t-1}+ \\
& +\beta_{3} s b c_{j, t-1}+\beta_{4} f b c_{j, t}+\beta_{5} c f l o w_{-} a s_{i, t}+\beta_{6} f m s_{j, t-1}+\beta_{7} f m s^{2}{ }_{j, t-1} \\
& +\beta_{8} g d p_{-} p c_{j, t}+\beta_{9} c o m p_{-} p c_{j, t}+\beta_{10} l t_{-} i r_{j, t}+\beta_{11} p o p_{-} d e n s_{j, t}+\eta_{t}+\varphi_{i}+\psi_{i t}
\end{aligned}
$$

where $\beta_{0}=\lambda, \beta_{1}=\alpha(1-\lambda)$ and $\beta_{2}=-\alpha(1-\delta)(1-\lambda)$ according to the dynamic accelerator model (equation (8)). $\beta_{0}$ represents the coefficient of the lagged dependent variable. $\beta_{1}$ measures the investment-output sensitivity which depends on the adjustment process. Note that the difference between $\beta_{1}$ and $\beta_{2}$ is that $\beta_{2}$ also captures the rate of replacement investment.

Our baseline specification includes the regulatory-induced service-based competition variable, $s b c_{j, t-1}$, and the facility-based competition variable, $f b c_{j, t}$ as the main competition variables of interest. The latter variable measures the contemporaneous stock of infrastructure of the incumbents $\left(f b c_{-} i n c_{j, t}\right)$ and the entrants $\left(f b c_{-} e n t_{j, t}\right)$. In order to identify firm-level causal effects and strategic interactions, we estimate equation (9) separately for incumbents and entrants. The variables $f m s_{j, t-1}$ and $f m s_{j, t-1}^{2}$ capture a potential non-linear influence from intermodal wireless competition. Based on our dynamic investment accelerator model, we include sales_as $s_{i, t}$ and sales_as $a s_{i, t-1}$ as well as the lagged dependent variable capex_as $s_{i, t-1}$. In addition, we include $c f l o w_{-} a s_{i, t}$ to control for firm-specific financial constraints, while the country level variables $g d p_{\_} p c_{j, t}$, comp_p $_{j, t}, l t_{-} i r_{j, t}$ and $p o p_{-} d e n s_{j, t}$ represent our 
demand and cost controls. Finally, $\gamma$ represents the intercept, $\varphi_{i}$ firm-specific fixed effects, $\eta_{t}$ time-specific effects, and $\psi_{i, t}$ represents the error term.

\subsection{Estimation and identification strategy}

In estimating the baseline specification in equation (9), we are confronted with several sources of endogeneity: first, there might be potential endogeneity in terms of reverse causality underlying our regulation and competition variables, which are partly driven by the level of investment. However, the causal link between an increase of the level of investment and the number of (regulated) broadband lines within a period of time will be mitigated, since switching the broadband operator is subject to inertia due to long-term contracts with consumers (typically up to two years). Notwithstanding this, we include the lagged value of the variable $s b c_{j, t-1}$ which further mitigates potential endogeneity in case there is no serial correlation in the original error term. However, we also have to take into account endogeneity due to unobserved heterogeneity and the presence of the lagged dependent variable as a right-hand side variable (Nickell, 1981).

Dynamic GMM panel data estimation techniques represent the most prominent candidate estimator that allows us to simultaneously consider all the aforementioned sources of endogeneity underlying our main explanatory variables related to competition in broadband markets as well as sales and cash flow at the firm level. Arellano and Bover (1995) and Blundell and Bond (1998) show by Monte Carlo analysis that their general method of moments system estimator (GMM-SYS) has a smaller bias than the general method of moments difference estimator (GMM-DIFF) initially developed by Arellano and Bond (1991) for finite samples. In addition, Bruno (2005a, 2005b) developed a bias-corrected LSDV estimator (LSDVC) for unbalanced and dynamic panel data, which however requires that all other right-hand side variables are strictly exogenous. Although it is reasonable to consider dynamic autoregressive models such as in equation (9) as dynamically complete (Wooldridge 2002, pp. 299-300), the underlying assumption is still restrictive and therefore we consider LSDVC estimations to test the robustness of our GMM-SYS estimation results. 


\section{Discussion of the main results}

Table 3 and Table 4 below show the main estimation results based on the specification in equation (9) for the incumbents and entrants. All standard errors reported are robust to arbitrary forms of heteroscedasticity and autocorrelation in the $\psi_{i, t}$ 's for GMM and bootstrapped for LSDVC models. ${ }^{8}$ The key identifying assumption underlying the GMM estimator is that the error terms in the original specification, $\psi_{i, t}$ 's, are serially uncorrelated. For all GMM models reported in Table 3 and Table 4 the Arellano-Bond $A R(2)$ and $A R(3)$ tests for zero autocorrelation in the first-differenced errors do not reject at order two and three at conventional levels, respectively. This implies, most importantly, that there is no evidence for serial correlation in the original error. Also, the Hansen-Sargan tests do not reject the over-identifying restrictions at the conventional levels in all GMM models. All explanatory variables, except cost and demand controls, are specified as endogenous in all GMM specifications. In order to avoid an over fitting bias in case of too many instruments employed in GMM models, we restrict the maximum number of lagged instruments to keep the total number of instruments close to the number of groups. Finally, Table 3 and Table 4 show regression results for alternative estimators (GMM-SYS vs. LSDVC) and for alternative selections of control variables. All the main variables of interest appear to be robust with respect to these alternative model specifications. ${ }^{9,10}$

First, as regards the coefficient of the lagged dependent variable, capex_as $a, t-1$, Table 3 and Table 4 show highly significant and substantial estimates in all regressions indicating that the dynamic baseline specification is adequate. As expected, the coefficient is between 0 and 1. The GMM coefficient estimates for the incumbent equation lie in the interval of $[0.434 ; 0.456]$ which is above the range of the corresponding GMM estimates for the entrant equation [0.329; 0.389]. This indicates that there are adjustment costs underlying NGA deployment which are apparently more

\footnotetext{
${ }^{8}$ Stata 13.1 is used to estimate the regressions.

9 This also applies when we further reduce the number of instruments by using the "collapse" option of STATA's "xtabond2" command (results are available upon request from the authors).

${ }^{10}$ Due to the variation in the entrants' firm size we also checked for potential outliers by excluding $1 \%$ of the largest observations. Estimation results remain robust and are available upon request from the authors.
} 
pronounced for the incumbents. A possible explanation for this is that investment data for the incumbent also contain investment in mobile network infrastructure, which involves comparatively high investment requirements and complex technical network planning as well as institutional rigidities due to limited spectrum licences. Another explanation would be that incumbents are simply larger and more diversified (active in all lines of businesses in the telecommunications sector), giving rise to smoother investment profiles than for entrants.

Second, the coefficient of the variable sales_as $s_{i, t}$ is significantly positive, whereas the coefficient estimate of the lagged sales variable, sales_as $s_{i, t-1}$, is significantly negative in all model specifications in Table 3 and Table 4 . In conjunction with the coefficient estimate of the lagged dependent variable, capex_as $s_{i, t-1}$, this represents strong supportive evidence for our dynamic flexible investment accelerator model as outlined in section 3.4. Additionally, we can distinguish between short- and long-run effects. ${ }^{11}$ An increase in sales_as by $10 \%$, increases the incumbents' capex_as $s_{i, t}$ by up to $2.6 \%$ in the short-run and by $4.6 \%$ in the long-run. An increase in sales_as by $10 \%$ increases the entrants' capex $_{a s}$ by up to $0.1 \%$ in the short-run and by $0.14 \%$ in the longrun. The low level of the coefficient estimate of the variables sales_as $s_{i, t}$ and sales_as $s_{i, t-1}$ for the entrants is mainly attributed to their low capital to output ratio $(\alpha \sim 0.008)$. The cash flow variable, $c f l o w_{-} a s_{i, t}$, shows positive and significant coefficient estimates for the entrants' equation in both GMM and LSDVC regressions. This indicates that entrants might face difficulties to borrow money externally on the financial markets due to their smaller average size, ownership structure or creditworthiness. The positive and significant coefficient estimate shows that imperfect capital markets lead entrants to increase their investment level when internal funds get higher. An increase in $c$ flow_as $a s_{i, t}$ by $10 \%$ increases the entrants' capex_as by up to $0.23 \%$ in the short-run and by $0.35 \%$ in the long-run.

Third, as regards facility-based competition in terms of the contemporaneous infrastructure stock, $f b c_{j, t}$, the corresponding variables of the incumbent and entrant

\footnotetext{
${ }^{11}$ Short-run coefficient $\left(\beta_{1}+\beta_{2}\right)$ for sales_as, analogous for the other coefficients and variables; long-run coefficient $\frac{\beta_{1}+\beta_{2}}{1-\beta_{0}}$ for sales_as, analogous for the other coefficients and variables.
} 
operators $\left(f b c_{-} i n c_{j, t}\right.$ and $\left.f b c_{-} e n t_{j, t}\right)$ exhibit significant and positive coefficient estimates throughout all regressions. This suggests that firms' investment decisions are strategic complements and investment decisions reinforce each other as hypothesized in section 3.3. This effect is more pronounced with respect to the entrants' equation. Hence, if regulatory policies - broadly understood encompassing any sector-specific regulations - exert a strong direct impact on investment of the incumbent operators, there is also a substantial indirect impact on the investment activities of entrants. An increase in $f b c_{-} e n t_{j, t}$ by 10 percentage points would lead to an increase in incumbents' capex_as by up to 1.8 percentage points in the short-run and by 3.1 percentage points in the longrun. On the other hand, an increase in $f b c_{-} i n c_{j, t}$ by 10 percentage points would lead to an increase in entrants' capex_as by up to 2.4 points in the short-run and by 3.7 percentage points in the long-run.

Fourth, facility-based intermodal competition in terms of fixed-mobile substitution is captured by the variables $f m s_{j, t-1}$ and $f m s_{j, t-1}^{2}$. Whereas the coefficient estimates of the incumbent regressions exhibit a clear non-linear pattern in terms of an inverted $U$ shape relation, the respective coefficient estimates are insignificant for the entrants' regressions. It thus appears that incumbent are more affected by intermodal competition than entrants. If we consider the results for the incumbent's specification in regressions (1) to (3) in Table 3, we find that a fixed-mobile ratio of around 4.3 is optimal for broadband investment of incumbents. According to Table 1 the mean value of the variable $f m s_{j, t-1}$ is around 4.6 and hence above the optimum value of $f m s_{j, t-1}$ that represents the maximum of the inverted $U$-shape relationship. As a consequence, intermodal competition from mobile networks exerted a positive impact on investment incentives of incumbent operators on average.

Finally, the market effect of service-based competition as measured by the variable $s b c_{j, t-1}$, which hinges on relevant wholesale broadband access regulations, appears to have no significant impact on the investment decisions of incumbents and entrants on average, i.e. during the overall period of analysis. Whereas regression (3) in Table 4 reports a negatively significant coefficient estimates for the entrant's equation, all other coefficient estimates are insignificant. The latter might be the outcome of the 
opposing effects as identified in section 3.1. However, the impact of service-based competition might also depend on the different phases of market liberalization. Most notably, it can be assumed that service-based competition promoted competition and investment in the early phase of liberalization when infrastructure-based competition has been hardly established. In turn, with increasing levels of infrastructure-based competition, the investment promoting role of service-based competition might have decreased. Moreover, entrants who enjoy favourable access conditions in terms of a broadly established wholesale access regime with low risks will not self-deploy highcost intense access infrastructure.

Table 5 reports GMM regression estimates for incumbents (regressions (1)-(2)) and entrants (regressions (3)-(4)) where we additionally included an interaction term, $i_{-} s b c_{j, t-1}$ dummy03_07, which captures the differential impact of service-based competition in the first phase of liberalization, i.e. for the years from 2003 to $2007 .^{12}$ The dummy variable takes on the value 1 for the years from 2003 to 2007, and the value 0 else. Indeed, we now find a neutral effect of service-based competition as regards entrants' investment in the early phase and a significantly negative impact for the late phase of liberalization, i.e. for the years from 2008 to 2012. The impact of service-based competition remains insignificant for the entire period of analysis for incumbents. Note also that all other coefficient estimates reported in Table 5 remain robust in view of the before-mentioned results.

\footnotetext{
${ }^{12}$ In defining the interaction term we equally split our period of observation. Estimation results, however, are robust towards different specifications of liberalization phases (results are available from the authors upon request).
} 
Table 3: Regression results for incumbents' equation

\begin{tabular}{|c|c|c|c|c|}
\hline & (1) & (2) & (3) & (4) \\
\hline Dependent variable: capex $a s_{i, t}$ & GMM SYS & GMM SYS & GMM SYS & LSDVC \\
\hline capex_as $s_{i, t-1}$ & $\begin{array}{l}0.434^{* *} \\
(0.029)\end{array}$ & $\begin{array}{l}0.439^{*} \\
(0.054)\end{array}$ & $\begin{array}{l}0.456^{* *} \\
(0.028)\end{array}$ & $\begin{array}{l}0.479^{* * *} \\
(0.000)\end{array}$ \\
\hline$s b c_{j, t-1}$ & $\begin{array}{l}0.147 \\
(0.350)\end{array}$ & $\begin{array}{l}0.124 \\
(0.115)\end{array}$ & $\begin{array}{l}0.068 \\
(0.292)\end{array}$ & $\begin{array}{l}-0.003 \\
(0.946)\end{array}$ \\
\hline$f b c \_e n t_{j, t}$ & $\begin{array}{l}0.183^{\star *} \\
(0.020)\end{array}$ & $\begin{array}{l}0.175^{\star} \\
(0.063)\end{array}$ & $\begin{array}{l}0.143^{*} \\
(0.078)\end{array}$ & $\begin{array}{l}0.112^{*} \\
(0.069)\end{array}$ \\
\hline sales_as $s_{i, t}$ & $\begin{array}{l}0.179^{* * *} \\
(0.001)\end{array}$ & $\begin{array}{l}0.178^{* * *} \\
(0.001)\end{array}$ & $\begin{array}{l}0.148^{* * *} \\
(0.000)\end{array}$ & $\begin{array}{l}0.126^{* * *} \\
(0.000)\end{array}$ \\
\hline sales_as $s_{i, t-1}$ & $\begin{array}{l}-0.079^{*} \\
(0.083)\end{array}$ & $\begin{array}{l}-0.080^{*} \\
(0.084)\end{array}$ & $\begin{array}{l}-0.069^{*} \\
(0.094)\end{array}$ & $\begin{array}{l}-0.057^{* *} \\
(0.024)\end{array}$ \\
\hline cflow_as $s_{i, t}$ & $\begin{array}{l}-0.080 \\
(0.526)\end{array}$ & $\begin{array}{l}-0.079 \\
(0.550)\end{array}$ & $\begin{array}{l}-0.039 \\
(0.661)\end{array}$ & $\begin{array}{l}0.097^{*} \\
(0.077)\end{array}$ \\
\hline$f m s_{j, t-1}$ & $\begin{array}{l}0.156^{\star *} \\
(0.026)\end{array}$ & $\begin{array}{l}0.154^{* *} \\
(0.027)\end{array}$ & $\begin{array}{l}0.157^{* *} \\
(0.022)\end{array}$ & $\begin{array}{l}0.022 \\
(0.753)\end{array}$ \\
\hline$f m s_{j, t-1}^{2}$ & $\begin{array}{l}-0.018^{\star *} \\
(0.029)\end{array}$ & $\begin{array}{l}-0.018^{* *} \\
(0.030)\end{array}$ & $\begin{array}{l}-0.018^{* *} \\
(0.023)\end{array}$ & $\begin{array}{l}-0.002 \\
(0.757)\end{array}$ \\
\hline$g d p \_p c_{j, t}$ & $\begin{array}{l}-1.53 e-10 \\
(0.420)\end{array}$ & $\begin{array}{l}1.49 e-10 \\
(0.415)\end{array}$ & & $\begin{array}{l}3.93 e-12 \\
(0.980)\end{array}$ \\
\hline It_ir $r_{j, t}$ & $\begin{array}{l}-0.001 \\
(0.840)\end{array}$ & $\begin{array}{l}-0.000 \\
(0.879)\end{array}$ & & $\begin{array}{l}-0.000 \\
(0.869)\end{array}$ \\
\hline pop_dens $s_{j, t}$ & $\begin{array}{l}-2.28 \mathrm{e}-06 \\
(0.942)\end{array}$ & & & $\begin{array}{l}0.000 \\
(0.532)\end{array}$ \\
\hline comp_pc $c_{j, t}$ & $\begin{array}{l}-1.80 \mathrm{e}-07 \\
(0.881)\end{array}$ & & & $\begin{array}{l}1.96 \mathrm{e}-08 \\
(0.981)\end{array}$ \\
\hline Constant & $\begin{array}{l}-0.418^{* *} \\
(0.017)\end{array}$ & $\begin{array}{l}-0.407^{* *} \\
(0.019)\end{array}$ & $\begin{array}{l}-0.377^{* *} \\
(0.021)\end{array}$ & \\
\hline $\mathrm{AR}(1)$ test $p$-value & 0.066 & 0.070 & 0.055 & \\
\hline $\operatorname{AR}(2)$ test $p$-value & 0.550 & 0.537 & 0.541 & \\
\hline $\begin{array}{l}\text { Hansen-Sargan-test } p \text {-value } \\
\text { R-sq.: within }\end{array}$ & 0.940 & 0.972 & 0.798 & \\
\hline $\begin{array}{l}\text { R-sq.: within } \\
\text { \#Instruments }\end{array}$ & 30 & 30 & 30 & 0.524 \\
\hline \#Observations & 170 & 170 & 170 & 170 \\
\hline
\end{tabular}

Regressions (1)-(3) employ the two-step GMM system estimator. Regression (1) represents the full specification, while in regressions (2) and (3) we gradually reduce the number of control variables. In regression (4) we estimate the full specification using the LSDVC estimator. Since year dummies were jointly insignificant, we did not include them. Regressions (1)-(4) include firm fixed effects which we do not report for the sake of brevity. $p$-values for the $A R(1)$ and $A R(2)$ tests and the Hansen-Sargan test of over identifying restrictions are reported. $p$-values for estimated coefficients are reported in parentheses and are robust to heteroscedasticity in GMM estimates. In regressions (1)-(3) the lagged dependent variable, capex_as $s_{t-1}$, and the main explanatory variables, fbc_ent $t_{j, t}$, sales_as $s_{i, t}, c f l o w \_a s_{i, t}$ and $s b c_{j, t-1}$ are instrumented by a maximum number of $t-4$ lags. LSDVC standard errors are bootstrapped based on 100 iterations with bias correction for estimates up to order $\mathrm{O}(1 / \mathrm{T}) .{ }^{*} p<0.1 ;{ }^{* \star} p<0.05 ;{ }^{* \star *} p<0.01$ 
Table 4: Regression results for entrants' equation

\begin{tabular}{|c|c|c|c|c|}
\hline Dependent variable: $c a p e x \_a s_{i, t}$ & $\begin{array}{l}\text { (1) } \\
\text { GMM SYS }\end{array}$ & $\begin{array}{l}\text { (2) } \\
\text { GMM SYS }\end{array}$ & $\begin{array}{l}\text { (3) } \\
\text { GMM SYS }\end{array}$ & $\begin{array}{l}\text { LS) } \\
\text { LSDC }\end{array}$ \\
\hline capex_as $s_{i, t-1}$ & $\begin{array}{l}0.344^{\star \star *} \\
(0.000)\end{array}$ & $\begin{array}{l}0.329^{\star * *} \\
(0.000)\end{array}$ & $\begin{array}{l}0.389^{\star \star *} \\
(0.000)\end{array}$ & $\begin{array}{l}0.534^{\star \star \star} \\
(0.000)\end{array}$ \\
\hline$s b c_{j, t-1}$ & $\begin{array}{l}-0.103 \\
(0.383)\end{array}$ & $\begin{array}{l}-0.093 \\
(0.187)\end{array}$ & $\begin{array}{l}-0.152^{* *} \\
(0.015)\end{array}$ & $\begin{array}{l}0.028 \\
(0.842)\end{array}$ \\
\hline$f b c \_i n c_{i, t}$ & $\begin{array}{l}0.242^{* * *} \\
(0.004)\end{array}$ & $\begin{array}{l}0.230^{* * *} \\
(0.009)\end{array}$ & $\begin{array}{l}0.146^{* *} \\
(0.031)\end{array}$ & $\begin{array}{l}0.261^{* *} \\
(0.028)\end{array}$ \\
\hline sales_as $s_{i, t}$ & $\begin{array}{l}0.005^{\star * *} \\
(0.008)\end{array}$ & $\begin{array}{l}0.005^{\star * *} \\
(0.009)\end{array}$ & $\begin{array}{l}0.004^{* *} \\
(0.017)\end{array}$ & $\begin{array}{l}0.004^{* * *} \\
(0.000)\end{array}$ \\
\hline sales_as $s_{i, t-1}$ & $\begin{array}{l}-0.004^{* *} \\
(0.032)\end{array}$ & $\begin{array}{l}-0.004^{* *} \\
(0.029)\end{array}$ & $\begin{array}{l}-0.005^{* *} \\
(0.012)\end{array}$ & $\begin{array}{l}-0.005^{* * *} \\
(0.000)\end{array}$ \\
\hline cflow_as $s_{i, t}$ & $\begin{array}{l}0.023^{*} \\
(0.059)\end{array}$ & $\begin{array}{l}0.024^{\star *} \\
(0.049)\end{array}$ & $\begin{array}{l}0.024^{* *} \\
(0.043)\end{array}$ & $\begin{array}{l}0.035^{* * *} \\
(0.000)\end{array}$ \\
\hline$f m s_{j, t-1}$ & $\begin{array}{l}-0.039 \\
(0.790)\end{array}$ & $\begin{array}{l}-0.600 \\
(0.558)\end{array}$ & $\begin{array}{l}-0.052 \\
(0.649)\end{array}$ & $\begin{array}{l}0.321 \\
(0.139)\end{array}$ \\
\hline$f m s_{j, t-1}^{2}$ & $\begin{array}{l}0.008 \\
(0.584)\end{array}$ & $\begin{array}{l}0.010 \\
(0.413)\end{array}$ & $\begin{array}{l}0.009 \\
(0.472)\end{array}$ & $\begin{array}{l}-0.035 \\
(0.132)\end{array}$ \\
\hline$g d p \_p c_{j, t}$ & $\begin{array}{l}6.34 \mathrm{e}-09 \\
(0.549)\end{array}$ & $\begin{array}{l}3.80 \mathrm{e}-09 \\
(0.577)\end{array}$ & & $\begin{array}{l}-8.25 e-09 \\
(0.935)\end{array}$ \\
\hline It_ir $r_{j, t}$ & $\begin{array}{l}0.008 \\
(0.273)\end{array}$ & $\begin{array}{l}0.004 \\
(0.460)\end{array}$ & & $\begin{array}{l}-0.002 \\
(0.847)\end{array}$ \\
\hline pop_dens $s_{j, t}$ & $\begin{array}{l}0.000 \\
(0.965)\end{array}$ & & & $\begin{array}{l}-0.007 \\
(0.186)\end{array}$ \\
\hline comp_pc $c_{j, t}$ & $\begin{array}{l}2.34 \mathrm{e}-07 \\
(0.876)\end{array}$ & & & $\begin{array}{l}-6.90 e-08 \\
(0.979)\end{array}$ \\
\hline Constant & $\begin{array}{l}-0.023 \\
(0.955)\end{array}$ & $\begin{array}{l}0.058 \\
(0.761)\end{array}$ & $\begin{array}{l}0.143 \\
(0.542)\end{array}$ & \\
\hline AR(1) test $p$-value & 0.417 & 0.368 & 0.250 & \\
\hline $\operatorname{AR}(2)$ test $p$-value & 0.072 & 0.054 & 0.043 & \\
\hline AR(3) test $p$-value & 0.949 & 0.893 & 0.801 & \\
\hline $\begin{array}{l}\text { Hansen-Sargan test } p \text {-value } \\
\text { R-sq.: within }\end{array}$ & 0.935 & 0.940 & 0.833 & 0.584 \\
\hline \#Instruments & 48 & 48 & 48 & \\
\hline \#Observations & 177 & 177 & 177 & 177 \\
\hline
\end{tabular}

Regressions (1)-(3) employ the two-step GMM system estimator. Regression (1) represents the full specification, while in regressions (2) and (3) we gradually reduce the number of control variables. In regression (4) we estimate the full specification using the LSDVC estimator. Since year dummies were jointly insignificant, we did not include them. Regressions (1)-(4) include firm fixed effects which we do not report for the sake of brevity. $p$-values for the AR(1) and AR(2) tests and the Hansen-Sargan test of over identifying restrictions are reported. $p$-values for estimated coefficients are reported in parentheses and are robust to heteroscedasticity in GMM estimates. In regressions (1)-(3) the lagged dependent variable, capex $a s_{t-1}$, and the main explanatory variables $f b c$ ent $t_{j, t}$, sales as $s_{i, t}$, cflow $a s_{i, t}$ and $s b c_{i, t-1}$ are instrumented by a maximum number of $t-5$ lags, starting from $t-3$ due to a significant value of the $A R(2)$ test, therefore we also report the $A R(3)$ test $p$-value for regressions (1)-(3). LSDVC standard errors are bootstrapped based on 100 iterations with bias correction for estimates up to order $\mathrm{O}(1 / \mathrm{T})$. ${ }^{*} p<0.1 ;{ }^{* *} p<0.05 ;{ }^{* * *} p<0.01$. 
Table 5: Regression results for different phases of liberalization

\begin{tabular}{|c|c|c|c|c|}
\hline \multirow{3}{*}{$\begin{array}{l}\text { Dependent variable: } \\
\text { capex_as } s_{i, t}\end{array}$} & (1) & (2) & (3) & (4) \\
\hline & \multicolumn{2}{|c|}{ Incumbent } & \multicolumn{2}{|c|}{ Entrants } \\
\hline & GMM SYS & GMM SYS & GMM SYS & GMM SYS \\
\hline \multirow{2}{*}{ capex_as $s_{i, t-1}$} & $0.448^{* *}$ & $0.469^{\star \star}$ & $0.407^{\star \star \star}$ & $0.394^{* * *}$ \\
\hline & $(0.045)$ & $(0.035)$ & $(0.000)$ & $(0.000)$ \\
\hline \multirow[t]{2}{*}{$s b c_{j, t-1}$} & 0.164 & 0.061 & $-0.179^{*}$ & $-0.160^{*}$ \\
\hline & $(0.324)$ & $(0.331)$ & $(0.077)$ & $(0.058)$ \\
\hline \multirow{2}{*}{ i_sbc $c_{j, t-1} \_d u m m y 03 \_07$} & -0.018 & -0.029 & $0.199^{* * *}$ & $0.161^{* * *}$ \\
\hline & $(0.673)$ & $(0.465)$ & $(0.002)$ & $(0.000)$ \\
\hline$f b c \_e n t_{j, t}$ & $0.173^{* *}$ & $0.124^{*}$ & & \\
\hline \multirow{2}{*}{$f b c \_i n c_{j, t}$} & & & $0.180^{* *}$ & $0.165^{\star}$ \\
\hline & & & $(0.026)$ & $(0.072)$ \\
\hline \multirow[t]{2}{*}{ sales_as $i_{i, t}$} & $0.188^{\star * *}$ & $0.165^{\star * *}$ & $0.005^{* *}$ & $0.005^{* *}$ \\
\hline & $(0.000)$ & $(0.000)$ & $(0.020)$ & $(0.018)$ \\
\hline \multirow[t]{2}{*}{ sales_as $s_{i, t-1}$} & -0.085 & $-0.081^{*}$ & $-0.006^{* *}$ & $-0.006^{* * *}$ \\
\hline & $(0.106)$ & $(0.087)$ & $(0.011)$ & $(0.008)$ \\
\hline \multirow[t]{2}{*}{ cflow_as $s_{i, t}$} & -0.104 & -0.072 & $0.028^{* * *}$ & $0.027^{* \star *}$ \\
\hline & $(0.435)$ & $(0.431)$ & $(0.001)$ & $(0.003)$ \\
\hline \multirow{2}{*}{$f m s_{j, t-1}$} & $0.160^{*}$ & $0.153^{*}$ & -0.161 & 0.000 \\
\hline & $(0.058)$ & $(0.067)$ & $(0.180)$ & $(0.998)$ \\
\hline \multirow[t]{2}{*}{$f m s_{j, t-1}^{2}$} & $-0.018^{*}$ & $-0.017^{*}$ & $0.021^{*}$ & 0.002 \\
\hline & $(0.087)$ & $(0.092)$ & $(0.093)$ & $(0.891)$ \\
\hline \multirow[t]{2}{*}{$g d p \_p c_{j, t}$} & $1.38 e-10$ & & $1.45 e-09$ & \\
\hline & $(0.416)$ & & $(0.320)$ & \\
\hline \multirow[t]{2}{*}{ It_ir $r_{j, t}$} & 0.001 & & 0.006 & \\
\hline & $(0.773)$ & & $(0.355)$ & \\
\hline \multirow{2}{*}{ pop_dens $s_{j, t}$} & 0.000 & & -0.000 & \\
\hline & $(0.686)$ & & $(0.460)$ & \\
\hline comp_pc $c_{j, t}$ & $-3.95 \mathrm{e}-07$ & & $\begin{array}{l}1.57 \mathrm{e}-06 \\
(0282)\end{array}$ & \\
\hline \multirow{2}{*}{ Constant } & $-0.426^{* *}$ & $-0.368^{*}$ & 0.336 & 0.030 \\
\hline & 0.032 & $(0.054)$ & 0.297 & 0.924 \\
\hline AR(1) test $p$-value & 0.081 & 0.053 & 0.134 & 0.155 \\
\hline $\operatorname{AR}(2)$ test $p$-value & 0.532 & 0.463 & 0.035 & 0.037 \\
\hline $\operatorname{AR}(3)$ test $p$-value & & & 0.145 & 0.159 \\
\hline Hansen-Sargan test $p$-value & 0.994 & 0.988 & 0.992 & 0.990 \\
\hline \#Instruments & 29 & 29 & 57 & 55 \\
\hline \#Observations & 170 & 170 & 177 & 177 \\
\hline
\end{tabular}

Regressions (1)-(4) employ the two-step GMM system estimator. Regressions (1) and (3) represent the full specification, while in regressions (2) and (4) we reduce the number of control variables. Since year dummies were jointly insignificant, we did not include them. Regressions (1)-(4) include firm fixed effects which we do not report for the sake of brevity. $p$-values for the $A R(1), A R(2)$ and $A R(3)$ tests and the Hansen-Sargan test of over identifying restrictions are reported. $p$-values for estimated coefficients are reported in parentheses and are robust to heteroscedasticity in GMM estimates. In regressions (1)-(4) the lagged dependent variable, capex_as $s_{i, t-1}$, and the main explanatory variables, fbc_ent $t_{j, t}$, sales_as $s_{i, t}, c f l o w_{-} a s_{i, t}$ and $s b c_{j, t-1}$ are instrumented by maximum number of $t$ - 4 lags. In regressions (3) - (4) the lagged dependent variable, capex_as $s_{t-1}$, and the main explanatory variables, fbc_ent $t_{j, t}$, sales_as $s_{i, t}, c f l o w_{-} a s_{i, t}$ and $s b c_{j, t-1}$ are instrumented by maximum number of $t-5$ lags, starting from $t-3$ due to a significant value of the $\operatorname{AR}(2)$ test, therefore we also report the $\operatorname{AR}(3)$ test $p$-value for regressions (3)-(4). ${ }^{*} p<0.1 ;{ }^{* *} p<0.05 ;{ }^{* *} p<0.01$. 


\section{Summary and conclusions}

This paper intends to assess the impact of the main modes of competition on investment in broadband markets utilizing firm level data for European incumbent and entrant operators in the decade from 2003 to 2012. The period of analysis thus represents the phase of first-generation broadband competition and regulation. The econometric specification controls for various sources of endogeneity and accommodates separate firm-level investment specifications for (regulated) incumbent and (unregulated) entrant operators. The latter allows to test whether investment decisions are strategic complements or substitutes. Finally, investment dynamics are explicitly modelled in terms of a flexible accelerator model.

We first find that firm-level investment activities are subject to adjustment costs which are more pronounced for the incumbent operators. Second, we find that intermodal competition in terms of fixed-mobile substitution exerted a non-linear impact on incumbents' investment in terms of an inverted U-shape. This is partly in line with previous studies (e.g. Briglauer et al., 2013) but indicates that the overall impact on aggregate investment depends on the operator type. In turn, wireless competition had no significant impact on entrant's investment during the period of analysis. Third, wireline facility-based competition exerted a positive and substantial impact on investment for both types of operators and clearly outperforms service-based competition which had no significant impact for the average incumbent and entrant operator during the overall period of analysis. The role of facility-based competition appears to be even stronger as regards migration towards new fiber-based infrastructure which constitutes more symmetric market structures with new and additional market players (Bourreau et al., 2010, p. 693). Fourth, NRAs have to consider that investment related policy decisions will exert a direct and indirect impact since firms' investment decisions are strategic complements which reinforce the impact of an erroneous decision. NRAs claiming that service-based competition based on mandatory broadband access regulations remain necessary in the future shall thus bear the burden of proving convincingly that asymmetric market interventionism can be expected to be welfare enhancing. 
Finally, as regards the late phase of market liberalization, service-based competition exerted a significantly negative impact on entrants' investment activities. Hence, data from a decade of broadband access regulation are at odds with one of the main guiding regulatory principles of the EU regulatory framework according to which service-based competition also promotes investment in terms of infrastructure competition in the long-term. This also casts doubt on future regulatory access policies which continue to foresee multi-layer access obligations and service-based competition as a guiding principle for emerging fibre-based access networks (European Commission, 2010, recital 3). The higher the emphasis on dynamic efficiency is, the more the "regulatory frontier" is shifted towards softer regulation or symmetric regulation in terms of an industry coordinating role and enabling cooperation models (Vogelsang 2013, p. 215). 


\section{Acknowledgements}

The authors are grateful to the special issue guest editors as well as to two anonymous referees for highly valuable and insightful comments.

\section{Appendix}

The dynamic flexible accelerator model

By lagging equation (5) we obtain:

$$
I_{i, t-1}=K_{i, t-1}-(1-\delta) K_{i, t-2}
$$

Solving for $K_{i, t-2}$ we obtain:

$$
K_{i, t-2}=\frac{K_{i, t-1}-I_{i, t-1}}{1-\delta}
$$

By lagging equation (6) we obtain:

$$
K_{i, t-1}=(1-\lambda) K_{i, t-1}^{*}+\lambda K_{i, t-2}
$$

Next we insert equation (1) in equation (7) and obtain:

$$
I_{i, t}=\alpha(1-\lambda) Y_{i, t}-(1-\delta) K_{i, t-1}+\lambda K_{i, t-1}
$$

In the equation (A.14) we insert equation (A.13) and obtain:

$$
\left.I_{i, t}=\alpha(1-\lambda) Y_{i, t}-(1-\delta)\left\lfloor(1-\lambda) K_{i, t-1}^{*}+\lambda K_{i, t-2}\right\rfloor+\lambda \mid(1-\lambda) K_{i, t-1}^{*}+\lambda K_{i, t-2}\right\rfloor
$$

Next we reformulate equation (A.15) and obtain:

$$
I_{i, t}=\alpha(1-\lambda) Y_{i, t}-(1-\delta)(1-\lambda) K_{i, t-1}^{*}-\lambda(1-\delta) K_{i, t-2}+\lambda(1-\lambda) K_{i, t-1}^{*}+\lambda^{2} K_{i, t-2}
$$

Now we combine equation (1) and (A.16) and insert the resulting expression in equation (A.12) and obtain: 


$$
I_{i, t}=\alpha(1-\lambda) Y_{i, t}-\alpha(1-\delta)(1-\lambda) Y_{i, t-1}-\lambda(1-\delta) \frac{K_{i, t-1}-I_{i, t-1}}{1-\delta}+\lambda(1-\lambda) K_{i, t-1}^{*}+\lambda^{2} K_{i, t-2}
$$

Next we reformulate equation (A.17) and obtain:

$$
I_{i, t}=\alpha(1-\lambda) Y_{i, t}-\alpha(1-\delta)(1-\lambda) Y_{i, t-1}+\lambda I_{i, t-1}-\lambda K_{i, t-1}+\lambda(1-\lambda) K_{i, t-1}^{*}+\lambda^{2} K_{i, t-2}
$$

Again we insert equation (A.13) in the equation (A.18) and obtain:

$$
I_{i, t}=\alpha(1-\lambda) Y_{i, t}-\alpha(1-\delta)(1-\lambda) Y_{i, t-1}+\lambda I_{i, t-1}-\lambda\left[(1-\lambda) K_{i, t-1}^{*}+\lambda K_{i, t-2}\right]+\lambda(1-\lambda) K_{i, t-1}^{*}+\lambda^{2} K_{i, t-2}
$$

Next we reformulate equation (A.19) and obtain:

$$
I_{i, t}=\alpha(1-\lambda) Y_{i, t}-\alpha(1-\delta)(1-\lambda) Y_{i, t-1}+\lambda I_{i, t-1}-\lambda(1-\lambda) K_{i, t-1}^{*}-\lambda^{2} K_{i, t-2}+\lambda(1-\lambda) K_{i, t-1}^{*}+\lambda^{2} K_{i, t-2}
$$

Finally, we reformulate equation (A.20) and obtain our dynamic flexible accelerator investment model:

$$
I_{i, t}=\lambda I_{i, t-1}+\alpha(1-\lambda) Y_{i, t}-\alpha(1-\delta)(1-\lambda) Y_{i, t-1}
$$




\section{References}

Arellano, M., \& Bond, S. (1991). Some Tests of Specification for Panel Data: Monte Carlo Evidence and an Application to Employment Equations. Review of Economic Studies, 58, 277-297.

Arellano, M., \& Bover, O. (1995). Another Look at the Instrumental-Variable Estimation of Error-Components Models. Journal of Econometrics, 68, 29-51.

Bacache, M., Bourreau, M., \& Gaudin, G. (2014). Dynamic Entry and Investment in New Infrastructures: Empirical Evidence from the Fixed Broadband Industry. Review of Industrial Organization, 44, 179-209.

Bender, C. M., \& Goetz, G. (2011). Coexistence of Service- and Facility-Based Competition: The Relevance of Access Prices for "Make-or-Buy"-Decisions. MAGKS Discussion Paper, 7.

Blundell, R., \& Bond, S. (1998). Initial Conditions and Moment Restrictions in Dynamic Panel Data Models. Journal of Econometrics, 87, 115-143.

Bond, S., Elston, J. A., Mairesse, J., \& Mulkay, B. (2003). Financial Factors and Investment in Belgium, France, Germany, and the United Kingdom: A Comparison Using Company Panel Data. Review of Economics and Statistics, 85, 153-165.

Bouckaert, J., van Dijk, T., \& Verboven, F. (2010). Access regulation, competition, and broadband penetration: An international study. Telecommunications Policy, 34, 661-671.

Bourreau, M., Cambini, C., \& Doğan, P. (2012). Access pricing, competition, and incentives to migrate from "old" to "new" technology. International Journal of Industrial Organization, 30(6), 713-723.

Bourreau, M., \& Doğan, P. (2006). Build-or-Buy Strategies in the Local Loop. The American Economic Review, 96(2), 72-76.

Bourreau, M., Doğan, P., \& Manant, M. (2010). A Critical Review of the Ladder of Investment Approach. Telecommunications Policy, 34, 683-696.

Briglauer, W., \& Gugler, K. (2013). The Deployment and Penetration of High-Speed Fiber Networks and Services: Why are European Member States Lagging Behind? Telecommunications Policy, 37, 819-835. 
Briglauer, W., Ecker, G., \& Gugler, K. (2013). The Impact of Infrastructure- and Servicebased Competition on the Deployment of Next Generation Access Networks:

Recent Evidence from the European Member States. Information Economics and Policy, 25, 142-153.

Bruno, G. (2005a). Approximating the Bias of the LSDV Estimator for Dynamic Unbalanced Panel Data Models. Economics Letters, 87, 361-366.

Bruno, G. (2005b). Estimation and Inference in Dynamic Unbalanced Panel Data Models with a Small Number of Individuals. The Stata Journal, 5, 473-500.

Cambini, C., \& Jiang, Y. (2009). Broadband Investment and Regulation: A Literature Review. Telecommunications Policy, 33, 559-574.

Cave, M. (2006). Encouraging Infrastructure Competition via the Ladder of Investment. Telecommunication Policy, 30, 223-237.

Cave, M., \& Vogelsang, I. (2003). How Access Pricing and Entry Interact. Telecommunications Policy, 27, 717-727.

Chirinko, R. S. (1993). Business Fixed Investment Spending: Modeling Strategies, Empirical Results, and Policy Implications. Journal of Economic Literature, 31(4), 1875-1911.

Crandall, R. W., Eisenach, J. A., \& Ingraham, A. T. (2013). The Long-run Effects of Copper-loop Unbundling and the Implications for Fiber. Telecommunications Policy, 37(4-5), 262-281.

Eisner, R. (1978). Factors in Business Investment. Cambridge, MA: NBER, (Chapter 4). Retrieved from http://www.nber.org/chapters/c3841.

ERG European Regulators Group. (2005). Broadband Market Competition Report. European Regulators Group. Retrieved from http://www.irg.eu/streaming/erg_05_23_broadbd_mrkt_comp_report_p.pdf?conte ntld=543362\&field=ATTACHED_FILE.

European Commission. (2010). Commission Recommendation of 20 September 2010 on Regulated Access to Next Generation Access Networks (NGA). Official Journal of the European Union, L251((2010/572/EU)), 35-48.

European Parliament \& Council. (2000). Regulation (EC) No 2887/2000 of the European Parliament and of the Council of 18 December 2000 on Unbundled Access to the Local Loop. Official Journal of the European Communities, $L(336)$, 4-8. 
European Parliament \& Council. (2002). Directive 2002/19/EC of the European Parliament and of the Council of 7 March 2002 on Access to, and Interconnection of, Electronic Communications Networks and Associated Facilities (Access Directive). Official Journal of the European Communities, L(108), 7-17.

Fazzari, S., Hubbard, R. G., \& Petersen, B. C. (1988). Financing Constraints and Corporate. Brookings Papers on Economic Activity, 141-206. Retrieved from http://www.brookings.edu/ /media/Projects/BPEA/1988\%201/1988a_bpea_fazza ri_hubbard_petersen_blinder_poterba.PDF.

Foros, O. (2004). Strategic Investments with Spillovers, Vertical Integration and Foreclosure in the Broadband Access Market. International Journal of Industrial Organization, 22, 1-24.

Gans, J. (2001). Regulating Private Infrastructure Investment: Optimal Pricing for Access to Essential Facilities. Journal of Regulatory Economics, 20, 167-189.

Grajek, M., \& Röller, L. H. (2011). Regulation and Investment in Network Industries: Evidence from European Telecoms. Journal of Law and Economics, 55, 189-216.

Gugler, K. (2003). Corporate Governance and Investment. International Journal of Economics and Business, 10(3), 261-289.

Guthrie, G. (2006). Regulating Infrastructure: The Impact on Risk and Investment. Journal of Economic Literature, 44(4), 925-972.

Jorgenson, D. W., \& Siebert, C. D. (1968, September). A Comparison of Alternative Theories of Corporate Investment Behavior. The American Economic Review, 58(4), 681-712. Retrieved from http://www.jstor.org/stable/1815529.

Kaplan, S. N., \& Zingales, L. (1997). Do Investment Cash Flow Sensitivities Provide Useful Measures of Financing Constraints? The Quarterly Journal of Economics, $112,169-215$.

Kotakorpi, K. (2006). Access Price Regulation, Investment and Entry in Telecommunications. International Journal of Industrial Organization, 24, 10131020.

Nardotto, M., Valletti, T., \& Verboven, F. (2015). Unbundling the Incumbent: Evidence from UK Broadband. Journal of the European Economic Association, 13(2), 330362.

Nickell, S. (1981). Biases in Dynamic Models with Fixed Effects. Econometrica, 49, 1417-1426. 
Pindyck, R. S. (2007). Mandatory Unbundling and Irreversible Investment in Telecom Networks. Review of Network Economics, 6, 274-298.

Sacco, D. \& Schmutzler, A. (2011), Is There a U-shaped Relation Between Competition and Investment?. International Journal of Industrial Organization, 29(1), 65-73.

Valletti, T. (2003). The Theory of Access Pricing and Its Linkage with Investment Incentives. Telecommunications Policy, 27, 659-675.

Vareda, J., \& Hoernig, S. (2010), Racing for Investment under Mandatory Access. The B.E. Journal of Economic Analysis \& Policy, 10(1), Article 67.

Vermeulen, P. (2002). Business Fixed Investment: Evidence of a Financial Accelerator in Europe. Oxford Bulletin of Economics and Statistics, 64, 217-235.

Vogelsang, I. (2013). The Endgame of Telecommunications Policy? A Survey. Review of Economics, 64(3), 193-269.

Wooldridge, J. (2002). Econometric Analysis of Cross Section and Panel Data. Cambridge, MA: The MIT Press. 